\title{
An Overview of Plagiochila porelloides (Marchantiophyta) as a New Environmentally Sustainable Green Corrosion Inhibitor for Mild Steel in Acidic Solution
}

\author{
Demet ÖZKIR ${ }^{1 *}$ \\ ${ }^{I}$ Niğde Ömer Halisdemir University, Faculty of Arts \& Sciences, Department of Chemistry, Niğde, \\ TURKEY
}

\begin{tabular}{lll}
\hline Received: 19 August 2021 & Revised: 15 Eylül 2021 & Accepted: 20 September 2021
\end{tabular}

\begin{abstract}
In this study, the corrosion inhibition effect of Plagiochila porelloides (Torr. ex Nees) Lindenb. extract, a Marchantiophyta species, on mild steel in hydrochloric acid solution at $298 \mathrm{~K}$ was investigated for the first time by applying electrochemical impedance spectroscopy (EIS), linear polarization (LPR) and potentiodynamic polarization techniques. Experiments were performed by immersing mild steel electrodes in acidic solutions containing different concentrations of Plagiochila porelloides extract for 1 hour before each electrochemical measurement to equilibrate with the aggressive solution. Liverwort extract showed a strong inhibitory effect as a result of 1 hour electrochemical experiments, and as the extract concentration increased, the protective effect of mild steel in acidic solutions raised. In addition, the surface images of the electrodes in $1.0 \mathrm{M} \mathrm{HCl}$ solutions with and without liverwort extract after 1-hour exposure were examined by an optical microscope and it was shown that the metal surface in the inhibited extract solution had a smoother appearance compared to the uninhibited metal surface. Electrochemical findings and surface images support each other.
\end{abstract}

Key words: Marchantiophyta, Plagiochila porelloides, Green inhibitor, EIS, Optical microscope.

\section{Asidik Cözeltide Yumuşak Çelik için Çevresel Olarak Sürdürülebilir Yeni Bir Yeşil Korozyon İnhibitörü Olarak Plagiochila porelloides (Marchantiophyta)'e Genel Bir Bakış}

$\ddot{O} z$

Bir Marchantiophyta türü olan Plagiochila porelloides (Torr. ex Nees) Lindenb. ekstraktının 298 K'de hidroklorik asit çözeltisindeki yumuşak çeliğin korozyonu üzerine inhibisyon etkisi, ilk kez bu çalışmada elektrokimyasal impedans spektroskopisi (EIS), lineer polarizasyon (LPR) ve potansiyodinamik polarizasyon yöntemleri uygulanarak araştırılmıştır. Deneyler, her elektrokimyasal ölçümden önce yumuşak çelik elektrotların agresif çözelti ile dengeye gelmesi için 1 saat boyunca farklı konsantrasyonlarda Plagiochila porelloides özütü içeren asidik çözeltilere daldırılmasıyla gerçekleştirilmiştir. Ciğerotu özütü 1 saatlik elektrokimyasal deneyler sonucunda, güçlü bir inhibitör etki göstererek özüt derişimi arttıkça, asidik çözeltilerdeki yumuşak çeliği koruma etkisi artmıştır. Ayrıca, 1 saatlik daldırma süresi sonrasında inhibitörlü ve inhibitörsüz $1,0 \mathrm{M} \mathrm{HCl}$ çözeltilerine daldırılan elektrotların yüzey morfolojileri optik mikroskopta incelenmiș ve inhibitörlü çözeltideki metal yüzeyinin inhibitörsüz olan metal yüzeyine göre daha düzgün bir görüntüye sahip olduğu gösterilmiştir. Elektrokimyasal bulgular ve yüzey görüntüleri birbirini destekler niteliktedir.

Anahtar kelimeler: Marchantiophyta, Plagiochila porelloides, Yeşil inhibitör, EIS, Optik mikroskop

\footnotetext{
* Corresponding author: dozkir@ohu.edu.tr

(C) 2021 All rights reserved / Tüm haklarl saklıdır.

To cite this article: Özkır D. 2021. An Overview of Plagiochila porelloides (Marchantiophyta) as a New Environmentally Sustainable Green Corrosion Inhibitor for Mild Steel in Acidic Solution. Anatolian Bryology. 7:2,119130.

(c) $\left(\begin{array}{c}()) \\ \text { (8) }\end{array}\right.$ This work is licensed under a Creative Commons Attribution-Non Commercial 4.0 International License.
} 


\section{Introduction}

Corrosion is a spontaneous process of metallic destruction by the reaction of the metallic material with its surrounding environment. It causes serious damage to the main structure of the metal and this is a global problem for many industries (Guruprasad and Sachin, 2021; Chaubey et al., 2021). Corrosion is a distressing process that can cause damage to an industrial plant, causing it to shut down. For this reason, it is tried to be prevented or slowed down by using substances (inhibitors) that will prevent the dissolution of metallic material, especially in an aqueous medium such as acid, or in other words, reduce the current density. There are many common acidic media inhibitors. The most preferred among these are organic compounds with aromatic rings and heteroatoms such as $\mathrm{N}, \mathrm{S}, \mathrm{P}, \mathrm{O}$ in the basic skeleton chain. The addition of such substances to the corrosive media is one of the most effective and suitable methods to protect the metallic material (Özkır and Çifcibaşı, 2017; Özkır, 2018; Özkır, 2019a; Özkır, 2019b). On the other hand, since these compounds can be both costly and toxic to the environment, this has led many researchers to examine natural products and therefore environmentally friendly green inhibitors. According to many research articles, it has been stated that the extracts obtained from the leaves, bark, seeds and roots of the plants exhibit effective inhibition because they contain active organic compounds such as alkaloids, flavonoids and terpenoids which are called secondary metabolites (Özkır and Ezer, 2020; Zhang et al., 2020; Salmasifar et al., 2021; Alrebh et al., 2021).

Secondary metabolites can effectively adsorb the metal surface and therefore can be applied as corrosion inhibitors without toxic effects due to their structure. In fact, it can be said that the plant extracts' ability to act as corrosion inhibitors is traditionally due to the presence of chemical structures similar to those of previously known organic molecules (Huang et al., 2016). In theory, there is an electron transfer from the $\pi$ electrons present in the structure of phenolic compounds to metals. When the metal receives the electron, it becomes more stable and prevents corrosion attack on the surface. Bryophytes, which are very rich in secondary metabolites, are a group of plants that reproduce by spores rather than flowers or seeds (Cansu et al. 2013, 2014; Tosun et al. 2015). They are usually found in a humid environment. Based on its rich source of secondary metabolites, Hypnum cupressiforme, a moss species, was applied for the first time as a green inhibitor on the corrosion of mild steel in the $1.0 \mathrm{M} \mathrm{HCl}$ solution. As a result of the first research in this field and our country, it was found that Hypnum cupressiforme extract significantly prevents corrosion of mild steel (Özkır and Ezer, 2020).

Based on this idea, in this study, the effect of $P$. porelloides, which is also rich in secondary metabolites and a kind of liverwort, on the corrosion of mild steel in acidic solution was studied for the first time in Turkey. Liverworts, along with mosses and hornworts, are classified by botanists as bryophytes-non-flowering plants that lack vascular tissue. They mostly live in moist soils such as mosses, on rocks, soil, rock outcrops and tree bases. Investigation of corrosion inhibitor effects for such natural plants is a separate application area and increases their diversity.

For this purpose, it was intended to analyse the influence of the $P$. porelloides extract as an inhibitor on the mild steel corrosion in hydrochloric acid solution by three different electrochemical tests with various concentrations. As result, it has been discussed that the applicability of non-toxic and environmentally friendly $P$. porelloides extract as an effective inhibitor for industrial processes.

\section{Materials and Methods}

\subsection{Plant material}

The $P$. porelloides specimens were collected from Sakarya-Karasu, $133 \mathrm{~m}, 41^{\circ} 03^{\prime} 45^{\prime \prime} \mathrm{N}, 30^{\circ} 42^{\prime} 41^{\prime \prime}$ E, on a rock in March 2018 and identified using relevant literatures (Smith, 1996; Paton, 1999). The image of a small part of $P$. porelloides in water taken using a stereo microscope (digital camera integrated OLYMPUS SZX7 model) is presented in Figure 1.

\subsection{Preparation of Plagiochila porelloides extract solutions}

Analytical reagent-grade hydrochloric acid (37\%) and distilled water were utilized for preparing all extract solutions. The liverwort samples were first cleaned of the soiled parts of the roots and dried at $80{ }^{\circ} \mathrm{C}$ for about 2 hours in an oven to prepare the stock solution of the extract. The dried samples were ground into powder in a pestle. $3 \mathrm{~g}$ of powdered liverwort samples were weighed and refluxed for 25 hours with the addition of sufficient distilled water in a $250 \mathrm{~mL}$ reaction flask. The liverwort extract was filtered after reflux treatment. When filtration was complete, the colour of the obtained extract was metallic copper (RGB value for colour conversion is $108 ; 63 ; 30$, respectively). Figure 2 presents the preparation flow chart of liverwort samples and stock solution. 


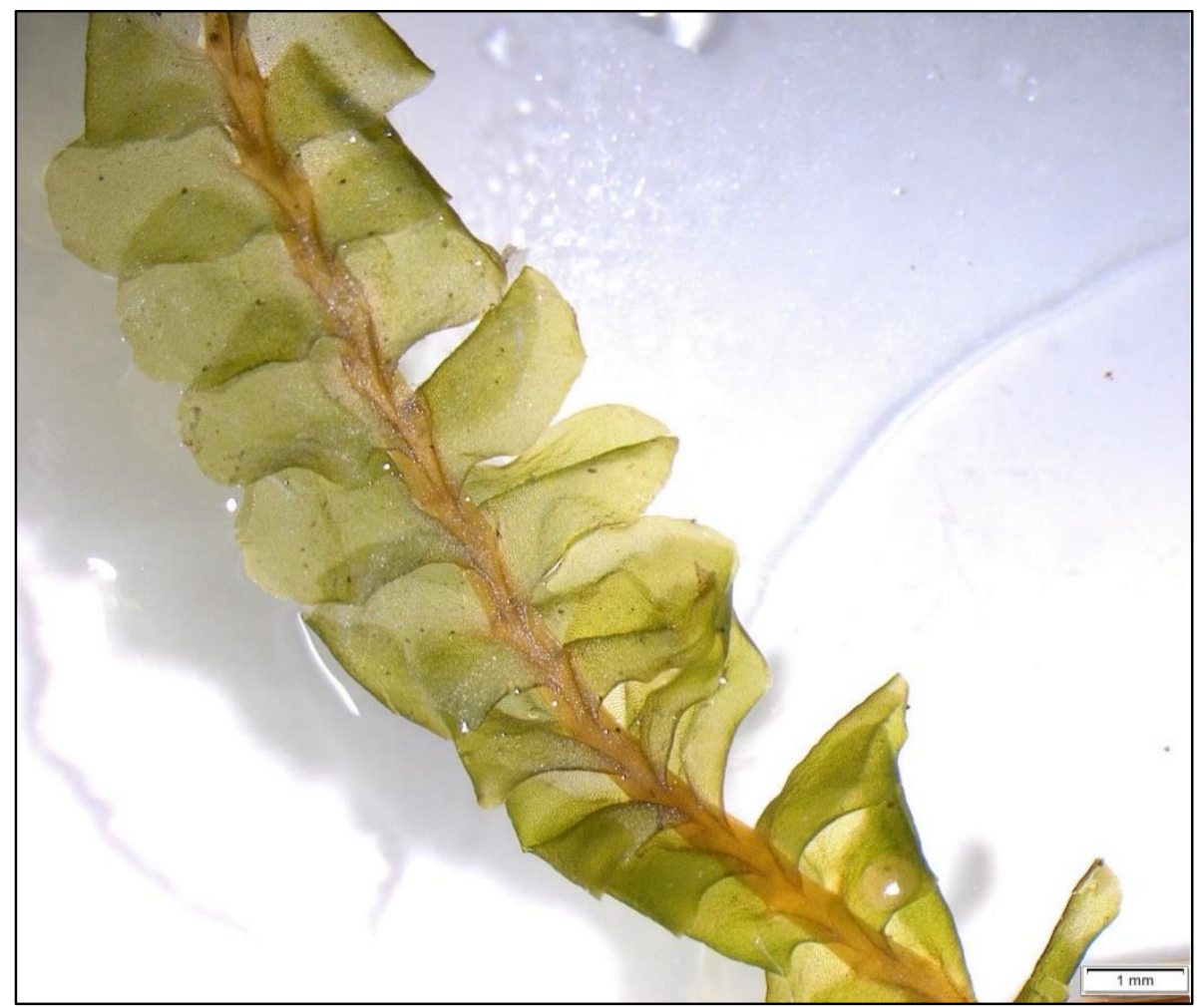

Figure 1. Stereo microscope image of $P$. porelloides

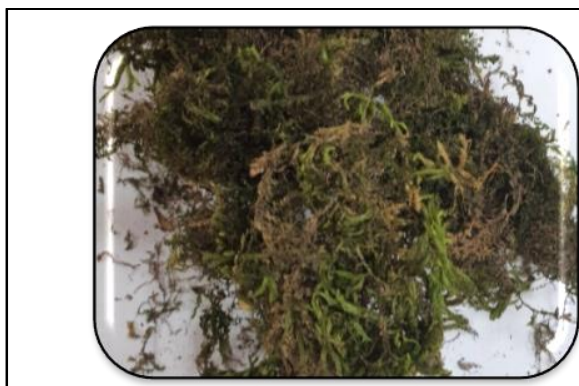

1) Before extraction

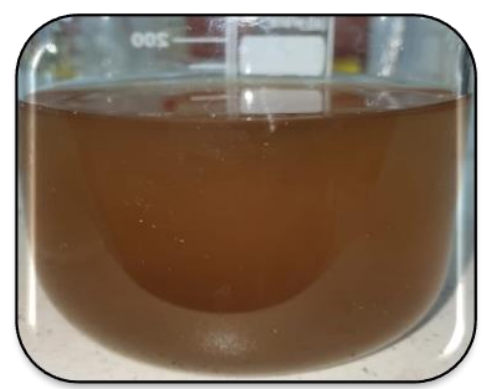

5) $P$. porelloides extract after filtration

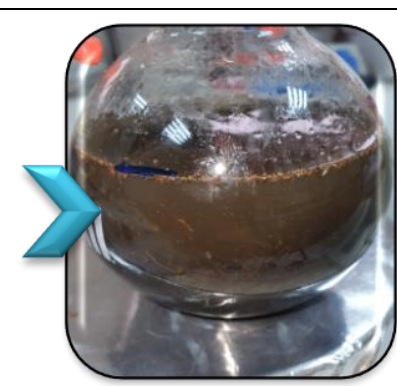

2) During extraction

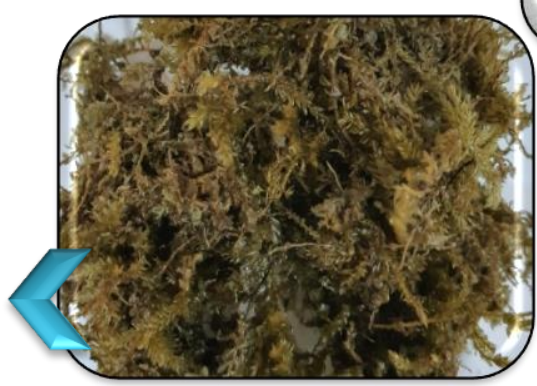

4) $P$. porelloides residue after filtration

Figure 2. Preparation step of $P$. porelloides extract

The concentration of the stock liverwort solution was determined as $0.115 \%(\mathrm{w} / \mathrm{v})$ by evaporation of $10 \mathrm{~mL}$ of the extract and weighed the residue. Other concentrations used in this study were prepared by dilution from the stock liverwort solution and the aggressive medium was provided with $1.0 \mathrm{M} \mathrm{HCl}$ solution. 


\subsection{Electrochemical measurements and} electrodes

The corrosion measurements of $P$. porelloides extract were obtained on the surface of mild steel electrodes. The chemical composition (wt.\%) of working electrodes is given in Table 1 . The working electrodes were prepared by placing them in a cylindrical mould containing a mixture of polyester-accelerator-hardener. Electrodes with a surface area of $0.5024 \mathrm{~cm}^{2}$ were exposed to hydrochloric acid solutions.

Table 1. The chemical composition of the working electrodes

\begin{tabular}{llllll}
\hline Element & \% & Element & $\%$ & Element & $\%$ \\
\hline$(\mathbf{C})$ & 0.08400 & $(\mathbf{S i})$ & 0.10200 & $(\mathbf{M n})$ & 0.40900 \\
$(\mathbf{P})$ & 0.01100 & $(\mathbf{S})$ & 0.01900 & $(\mathbf{C r})$ & 0.06030 \\
$(\mathbf{M o})$ & 0.01040 & $\mathbf{N i})$ & 0.07890 & $(\mathbf{A l})$ & Trace \\
$(\mathbf{C o})$ & 0.00198 & $(\mathbf{C u})$ & 0.21700 & $\mathbf{( N b )}$ & 0.00222 \\
$(\mathbf{T i})$ & Trace & $(\mathbf{V})$ & 0.01100 & $\mathbf{( W )}$ & Trace \\
$(\mathbf{P b})$ & Trace & $(\mathbf{S n})$ & 0.01620 & $\mathbf{( S b )}$ & Trace \\
$(\mathbf{F e})$ & Remain & & & & \\
\hline
\end{tabular}

Before each electrochemical test was applied, the surfaces of the working electrodes were polished with 150,600 , and 1000 grids of sandpapers, respectively. The electrode surfaces were cleaned with distilled water and acetone. The conventional three electrode methods were utilized for three electrochemical experiments. The first electrode is mild steel and was used as the working electrode. The second one, the counter electrode is a platinum plate with a surface area of $1.0 \mathrm{~cm}^{2}$, and the third one is $\mathrm{Ag} / \mathrm{AgCl}$ as the reference electrode. Electrochemical impedance spectroscopy (EIS), linear polarization resistance (LPR), and potentiodynamic polarization (Tafel extrapolation method) measurements were conducted using a computer-controlled CHI 660B model electrochemical analyser. These measurements were performed in hydrochloric acid solution without and with various $P$. porelloides extract concentrations. Before all experiments, all working electrodes were immersed in electrolyte solutions for 1 hour to stabilize the corrosion process at open circuit potential $\left(E_{\text {corr }}\right)$.

EIS tests were carried out at a frequency range of $10^{5}$ to $5 \times 10^{-3} \mathrm{~Hz}$ with $5 \mathrm{mV}$ amplitude applied to the corrosion process. LPR tests were performed at potential ranges of $\pm 10 \mathrm{mV}(\mathrm{Ag} / \mathrm{AgCl})$ from the corrosion potential with a scan rate of $0.1 \mathrm{mV} \mathrm{s}^{-1}$. Then, the polarization resistances $\left({ }^{*} R_{p}\right)$ were calculated from the slope of this curve by drawing a current versus potential plot. The potentiodynamic polarization curves were created by first applying -
$0.350 \mathrm{~V}$ from the corrosion potential to the cathodic potentials, and then $+0.350 \mathrm{~V}$ from the corrosion potential to the anodic potentials, with a scanning rate of $1.0 \mathrm{mV} \mathrm{s}^{-1}$. Corrosion current density values $\left(i_{\text {corr }}\right)$ of the system were calculated by the Tafel extrapolation method from these curves.

Surface images of working electrodes were taken 1 $\mathrm{h}$ of duration in the electrolyte solution $(1.0 \mathrm{M} \mathrm{HCl})$ with and without $P$. porelloides extract by using a digital camera integrated OLYMPUS BX-51 (Centre Valley, PA, USA) model optical microscope. Surface analyses were carried out only in $1.0 \mathrm{M} \mathrm{HCl}$ solutions with and without the highest concentration of $P$. porelloides extract. Experiments with three different techniques were conducted at ambient temperature $(298 \mathrm{~K})$.

\section{Results and Discussion}

\subsection{EIS and LPR measurement results}

EIS measurements were performed to evaluate the effect of various concentrations of $P$. porelloides extract solutions on the corrosion inhibition of mild steel. This method is a highly preferred corrosion technique because it is sourced from alternative current and does not distort the surface. The evaluated results are presented in Figure 3 in the form of Nyquist and Bode diagrams (Sürme and Gürten, 2009; Özkır, 2019c). As a result of the concentrations tried in this study, it was decided that the 6 most effective concentrations to be studied were $0.0005 \%, 0.0010 \%, 0.0025 \%, 0.0050 \%$, $0.0075 \%$ and $0.0100 \%(\mathrm{w} / \mathrm{v})$ respectively. 

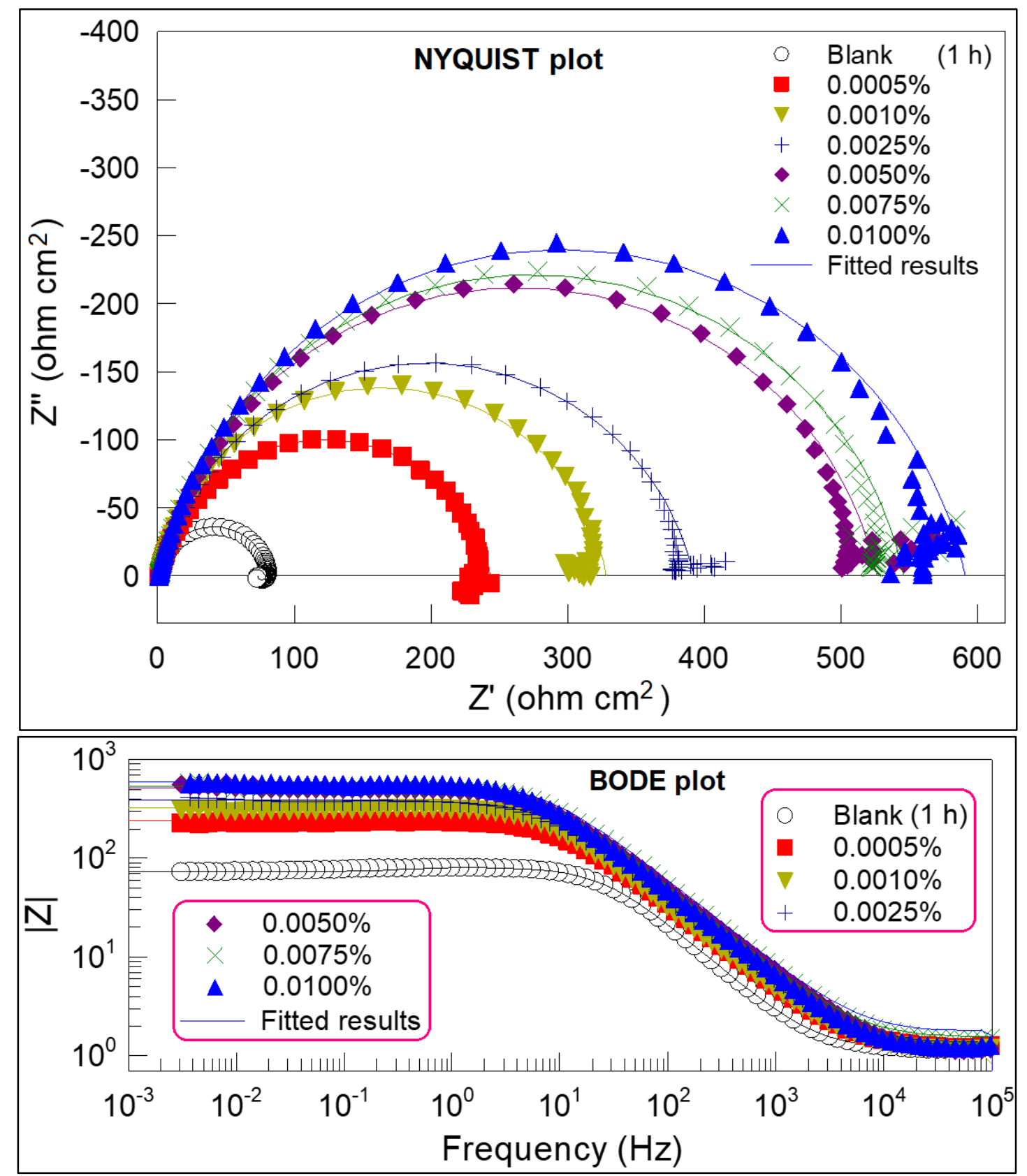

Figure 3. Nyquist and Bode plots of $P$. porelloides extract in $1.0 \mathrm{M} \mathrm{HCl}$ solution for $1 \mathrm{~h}$ immersion at 298 $\mathrm{K}$

EIS measurement data obtained by the experimental method were processed using Zview2 software and the equivalent circuits of the corrosion system were created separately for both the inhibited and

uninhibited solutions (Fig. 4). Figure 4 presents two types of equivalent circuit models. One is for the blank solution (a) and the other is for the system containing the extract solutions (b). 


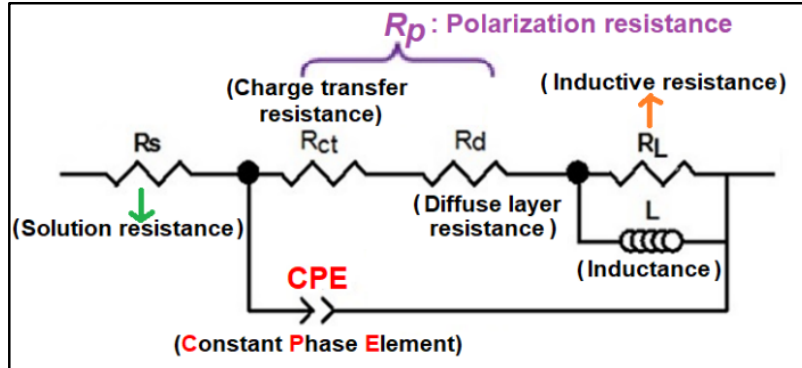

(a) Uninhibited system

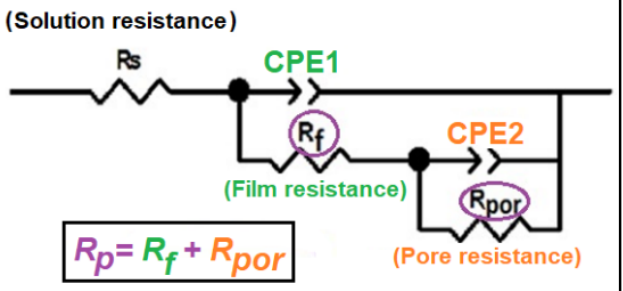

(b) Inhibited system

Figure 4. Proposed equivalent circuits for uninhibited (a) and all inhibited (b) solutions

According to Figure 4, the first difference between the two systems is the presence of film resistance $\left(R_{f}\right)$, which is caused by adsorption in the presence of an inhibitor. In addition, another difference is that the equivalent circuit model valid for the inhibited system does not include inductance $(L)$ and inductive resistance $\left(R_{L}\right)$, which only exist in the blank solution. Ultimately, these equivalent circuits describe that liverwort extracts are adsorbed onto the mild steel surface during the corrosion process. While the polarization resistance $\left(R_{p}\right)$ includes the diffuse layer $\left(R_{d}\right)$ and charge transfer $\left(R_{c t}\right)$ resistances in the uninhibited system, it is responsible for the sum of the film $\left(R_{f}\right)$ and pore $\left(R_{\text {por }}\right)$ resistances in all $P$. porelloides-containing solutions. Pore resistance appears as a summary of all the accumulated $\left(R_{a}\right)$ species, from the corrosion products formed there, to the diffuse layer and charge transfer, while the inhibitor is adsorbed on the mild steel surface. Therefore, it can be clearly said that all of these species contribute to the inhibition of the corrosion system.
Figure 3 will better explain the events on the surface. Looking at the Nyquist diagram, almost all of them are depressed semicircles. The fact that the semicircles are depressed explains the existence of two time constants, both high and low-frequency regions, as can be better understood from the Bode diagram. In the blank solution, capacitive (high frequency) and inductive (low frequency) loops are more dominant. According to both the Bode plot in Figure 3 and Figure 4a, the high-frequency region defines the polarization resistance, which includes the resistances of charge transfer and the diffuse layer. On the other hand, the low-frequency inductive loop represents the relaxation process. In solutions containing liverwort extract, it behaves as depressed capacitive loops in both low and highfrequency regions. Here, charge transfer and diffuse layer resistances are responsible for high frequency, while film resistance and all species accumulated on the surface are responsible for low frequency. The calculated EIS and "LPR parameters are indicated in Table 2 for $1 \mathrm{~h}$ immersion.

Table 2. EIS and LPR experiment parameters at $298 \mathrm{~K}$

\begin{tabular}{|c|c|c|c|c|c|c|c|c|c|c|}
\hline $\mathrm{C}(\mathrm{w} / \mathrm{v} \%)$ & $\begin{array}{c}E_{\text {corr }} \\
\text { (V/Ag/AgCl) }\end{array}$ & $\begin{array}{c}C P E \\
\left(\mu \mathrm{F} \mathrm{cm}^{-2}\right)\end{array}$ & $n$ & $\begin{array}{c}R_{s} \\
\left(\Omega \mathrm{cm}^{2}\right)\end{array}$ & $\begin{array}{c}R_{L} \\
\left(\Omega \mathrm{cm}^{2}\right)\end{array}$ & $\begin{array}{c}L \\
(\mathbf{H})\end{array}$ & $\begin{array}{c}R_{p} \\
\left(\Omega \mathrm{cm}^{2}\right)\end{array}$ & $\begin{array}{c}\eta \\
(\%)\end{array}$ & $\begin{array}{c}{ }^{*} R_{p} \\
\left(\Omega \mathbf{c m}^{2}\right)\end{array}$ & $\begin{array}{c}{ }^{*} \eta \\
(\%)\end{array}$ \\
\hline \multicolumn{11}{|l|}{ P.porelloides } \\
\hline Blank & -0.474 & 110 & 0.94 & 1.2 & 8 & 4 & 72 & - & 71 & - \\
\hline 0.0005 & -0.539 & 100 & 0.90 & 0.1 & - & - & 243 & 70.4 & 228 & 68.9 \\
\hline 0.0010 & -0.533 & 95 & 0.88 & 0.2 & - & - & 328 & 78.0 & 318 & 77.7 \\
\hline 0.0025 & -0.537 & 90 & 0.86 & 0.1 & - & - & 392 & 81.6 & 394 & 82. \\
\hline 0.0050 & -0.528 & 75 & 0.86 & 0.1 & - & - & 526 & 86.3 & 551 & 87.1 \\
\hline 0.0075 & -0.532 & 69 & 0.87 & 0.2 & - & - & 546 & 86.8 & 561 & 87.3 \\
\hline 0.0100 & -0.525 & 60 & 0.87 & 0.2 & - & - & 591 & 87.8 & 611 & 88.4 \\
\hline
\end{tabular}

${ }^{*} R_{p}$ and ${ }^{*} \eta$ : Values determined by linear polarization resistance method.

Looking at the EIS values, the polarization resistance $\left(R_{p}\right)$ of the blank solution was $72 \Omega$, but this value gradually increased with the addition of Plagiochila porelloides extract to the medium. The highest $R_{p}$ value was obtained with $0.0100 \%$ solution as $591 \Omega$. Accordingly, the best inhibition $(\eta \%)$ of mild steel in solution containing $1.0 \mathrm{M} \mathrm{HCl}$ by EIS was also calculated as $87.8 \%$ at this concentration. In this study, the effect of $P$. porelloides extract on corrosion inhibition of mild steel in acidic solution was discussed by determining the percent inhibition efficiencies for each concentration. $\eta \%$ and ${ }^{*} \eta \%$ values in EIS and LPR methods were calculated by the equation given below (Li et al., 2021). 
$\eta(\%)=\left(\frac{R_{p}^{\prime}-R_{p}}{R_{p}^{\prime}}\right) \times 100$

Where $R_{p}$ and $R_{p}^{\prime}$ and are in non-inhibited and inhibited polarization resistance values, respectively and $\eta \%$ is the percent inhibition efficiency value. CPE is the constant phase element and indicates the double layer formed at the interface between the metal and the solution. The $n$ value represents the surface inhomogeneity coefficient. Both mentioned values were obtained as a result of fitting the experimental data obtained with EIS via Zview2 software. CPE values are inversely proportional to inhibitor concentration and $R_{p}$ values. In other words, the more liverwort extract is adsorbed onto the mild steel surface, the smaller the CPE will be. As can be clearly seen from Table 2, as the inhibitor concentration enhanced, the polarization resistance values raised accordingly, whereas the CPE values diminished (Kumar and Yadav, 2020). CPE values ranged from $110 \mu \mathrm{F} \mathrm{cm}-$ ${ }^{2}$ to $60 \mu \mathrm{F} \mathrm{cm}{ }^{-2}$ with increasing concentration. The decrease in the $n$ values in Table 2 as the inhibitor concentration in the process raises is another indicator of the decrease in the surface roughness (Özkır et al., 2012; Charitha and Rao, 2018). The solution resistance, $R_{s}$, also did not change too much. Another important point is the corrosion potential $\left(E_{c o r r}\right)$, which is another determiner of inhibition in the environment, which is called the open circuit potential. While this value was -0.474 $\mathrm{V}$ in the blank solution, it shifted to more cathodic potentials with $P$. porelloides extract added to the solution.

The polarization resistance $\left({ }^{*} R_{p}\right)$ and the inhibition efficiency $\left({ }^{*} \eta \%\right)$ values calculated from the linear polarization plots are also shown in the far right column of Table 2 for $1 \mathrm{~h}$ immersion. The ${ }^{*} R_{p}$ values found by LPR and the " $\eta \%$ values calculated from them are in great harmony with the findings obtained by EIS, as can be clearly seen in Table 2 . It can be seen from Figure 3 and Table 2 that the adsorption of liverwort molecules on the mild steel surface is very evident with increasing resistance values as the liverwort extract is added to the $1.0 \mathrm{M}$ hydrochloric acid solution. From this, it can be deduced with a net inhibition result of $88 \%$ at the optimum concentration that liverwort molecules form a tight film on the mild steel surface and delay the charge transfer that takes place at the interface.
The main reason for the high inhibition effect of $P$. porelloides against mild steel in acidic solution can be attributed to the fact that it is a bryophyte species and the skeletal structure of the molecule contains important $\pi$-electron donors such as various phenolic compounds, terpenes, flavonoids, which are basically considered secondary metabolites. At this stage of the study, it can be interpreted that total inhibition occurs with all of the secondary metabolites in its structure. As a result, when the EIS and LPR measurements of this green inhibitor were taken into consideration after $1 \mathrm{~h}$ immersion, highly compatible and successful results were obtained.

\subsection{Potentiodynamic polarization measurement results}

The most well-known other name of this measurement is the Tafel extrapolation method, which covers semi-logarithmic current-potential curves. The aforementioned curves are indicated in Figure 5. Data calculated from potentiodynamic polarization curves for mild steel in $1.0 \mathrm{M}$ hydrochloric acid solution with and without $P$. porelloides extract at $298 \mathrm{~K}$ are tabulated in Table 3 . The inhibition efficiency $(\eta \%)$ values calculated by the Tafel extrapolation method were calculated by means of the Equation (2) below (El Tamany et al., 2018):

$$
\eta(\%)=\left(\frac{i_{\text {corr }}-i_{\text {corr }}^{\prime}}{i_{\text {corr }}}\right) \times 100
$$

Where $i_{\text {corr }}$ and $i_{\text {corr }}^{\prime}$ are blank and inhibited corrosion current densities, respectively.

The adsorption of $P$. porelloides molecules on the mild steel surface is affected by the increase in concentration, as seen in Figure 5. Especially when looking at the cathodic side, this is even more evident, and the cathodic polarization curves also decrease as the concentration increases. At the same time, as can be clearly seen from Table 3, the corrosion current density values $\left(i_{\text {corr }}\right)$ also diminish with increasing concentration. Therefore, the effectiveness of inhibition also rises. The cathodic Tafel constant $\left(-\beta_{c}\right)$ values were also defined by extrapolation of the potentiodynamic polarization plots. While the $-\beta_{c}$ value was $108 \mathrm{mV} \mathrm{dec}-1$ in the blank solution, it did not show much change in the solutions containing $P$. porelloides extract. The fact that this value does not change much means that the hydrogen evolution mechanism is not impressed by P. porelloides (Zohdy et al., 2021). 


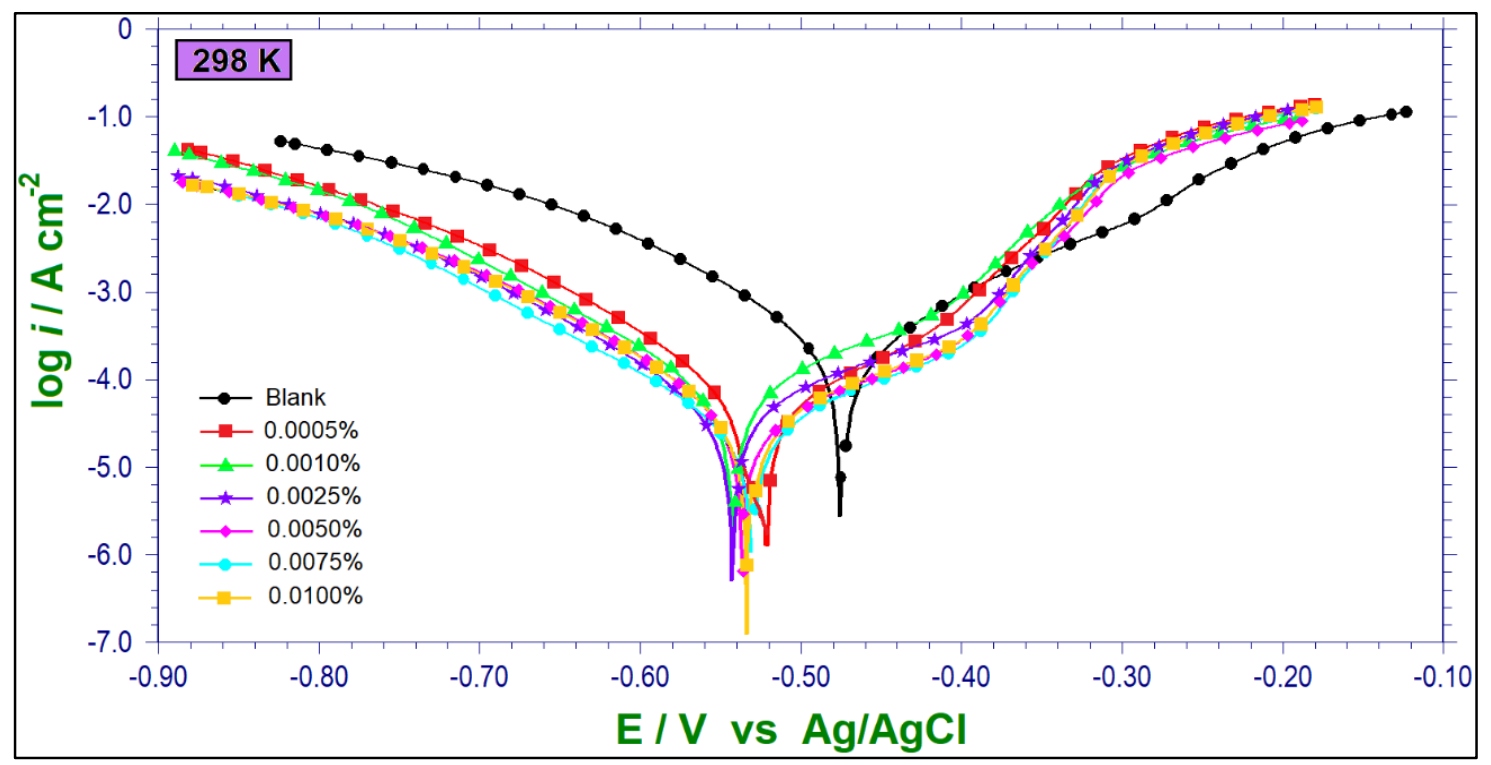

Figure 5. Potentiodynamic polarization plots for mild steel in $1.0 \mathrm{M} \mathrm{HCl}$ solution with and without $P$. porelloides extract as a green corrosion inhibitor at $298 \mathrm{~K}$

Table 3. Potentiodynamic polarization data calculated for mild steel in hydrochloric acid solution with and without $P$. porelloides extract

\begin{tabular}{|c|c|c|c|c|c|c|c|}
\hline \multirow{2}{*}{$(298 \mathrm{~K})$} & \multicolumn{7}{|c|}{ P. porelloides extract concentration (w/v \%) } \\
\hline & Blank & 0.0005 & 0.0010 & 0.0025 & 0.0050 & 0.0075 & 0.0100 \\
\hline $\begin{array}{c}\boldsymbol{E}_{\text {corr }} \\
(\mathrm{V} / \mathbf{A g} / \mathbf{A g C l})\end{array}$ & -0.475 & -0.534 & -0.541 & -0.536 & -0.539 & -0.530 & -0.530 \\
\hline $\begin{array}{c}-\beta_{c} \\
\left(\mathrm{mV} \operatorname{dec}^{-1}\right)\end{array}$ & 108 & 96 & 100 & 100 & 98 & 98 & 102 \\
\hline $\begin{array}{c}i_{c o r r} \\
\left(\mu \mathbf{A ~ c m}^{-2}\right)\end{array}$ & 265 & 73 & 62 & 43 & 37 & 35 & 25 \\
\hline $\begin{array}{c}\eta \\
(\%)\end{array}$ & - & 72.4 & 76.6 & 83.8 & 86.0 & 86.8 & 90.6 \\
\hline
\end{tabular}

While the $E_{\text {corr }}$ values of the potentiodynamic polarization plots in Figure 5 were $-0.475 \mathrm{~V}$ in the blank solution, they shifted to more negative (cathodic) potentials when the liverwort extract was added to the medium. The maximum potential change between blank and inhibitor-containing solutions is $66 \mathrm{mV}$ (Table 3). Since this potential change $(66 \mathrm{mV})$ is slightly lower than $85 \mathrm{mV}$, it can be said that the behaviour of the inhibitor in this electrolyte solution is close to the definition of a mixed-type inhibitor on the mild steel surface (Feng et al., 2021; Mao et al., 2021). The increment of the concentration of $P$. porelloides extract in hydrochloric acid solution attenuates the current densities and thus the slopes of both the cathodic and anodic polarization curves. However, the decrease in current density in the cathodic region is slightly more marked in solutions with inhibitors than in the blank solution and the anodic region. For this reason, P. porelloides extract acts as a cathodic controlled mixed-type inhibitor on the corrosion of mild steel in solution containing 1.0 M hydrochloric acid (Nam et al., 2018). While mixed-type inhibitors act on the metal surface, they play a role in both anodic and cathodic reactions. These inhibitors do not change the corrosion potential much, but reduce the corrosion current (Rodrigues et al., 2021).

When the results obtained with the three electrochemical techniques for liverwort extract were examined, the common point of inhibition efficiency values of all three were found to be compatible with each other in the six concentrations studied. The distribution range of $\eta \%$ values was calculated by EIS, LPR and potentiodynamic polarization method as $70.4 \%-87.8 \%, 68.9 \%$ $88.4 \%$, and $72.4 \%-90.6 \%$, respectively. The harmony of the three methods is better illustrated schematically in Figure 6. 


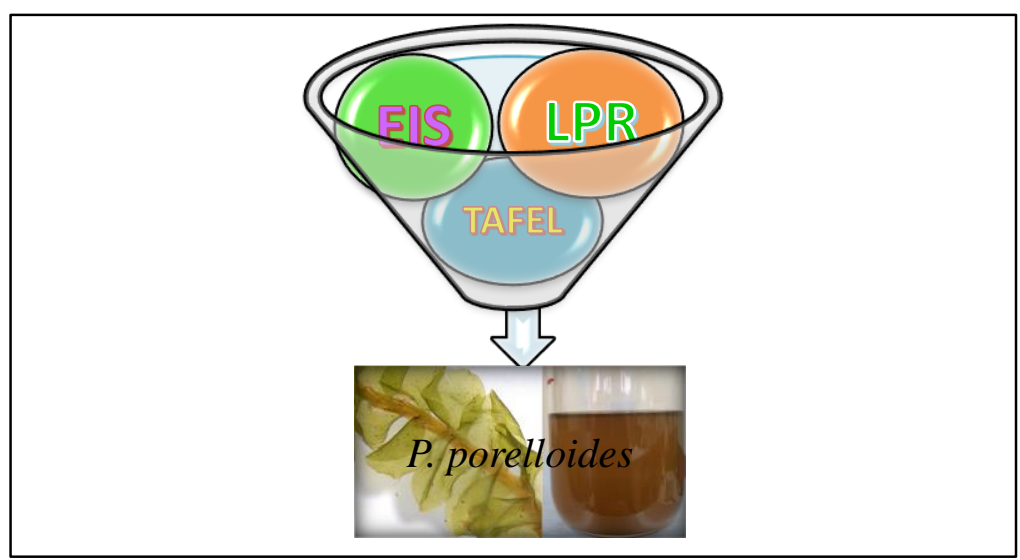

Figure 6. The schematic visual expression of three electrochemical corrosion measurement methods

3.3. The optical microscope results of working electrodes

The influence of preventive $P$. porelloides as green corrosion inhibitor adsorbed on mild steel in hydrochloric acid solution after $1 \mathrm{~h}$ of duration was viewed by using optical (metal) microscope method as shown in Figure 7 (Özkır and Kayakırılmaz, 2020; Abu-Baker et al., 2021; Ma et al., 2021). Surface images were only performed for $0.0100 \%$ (w/v) $P$. porelloides extract solutions with and without $1.0 \mathrm{M} \mathrm{HCl}$. In this final stage of the study, the experimental results obtained by electrochemical measurements are confirmed by surface images taken with an optical microscope. Figure 7(a) reveals the surface view of an untreated bare mild steel electrode. This surface was only sanded and polished before the image was taken. In the surface image, the traces caused by the sanding process are clearly visible.

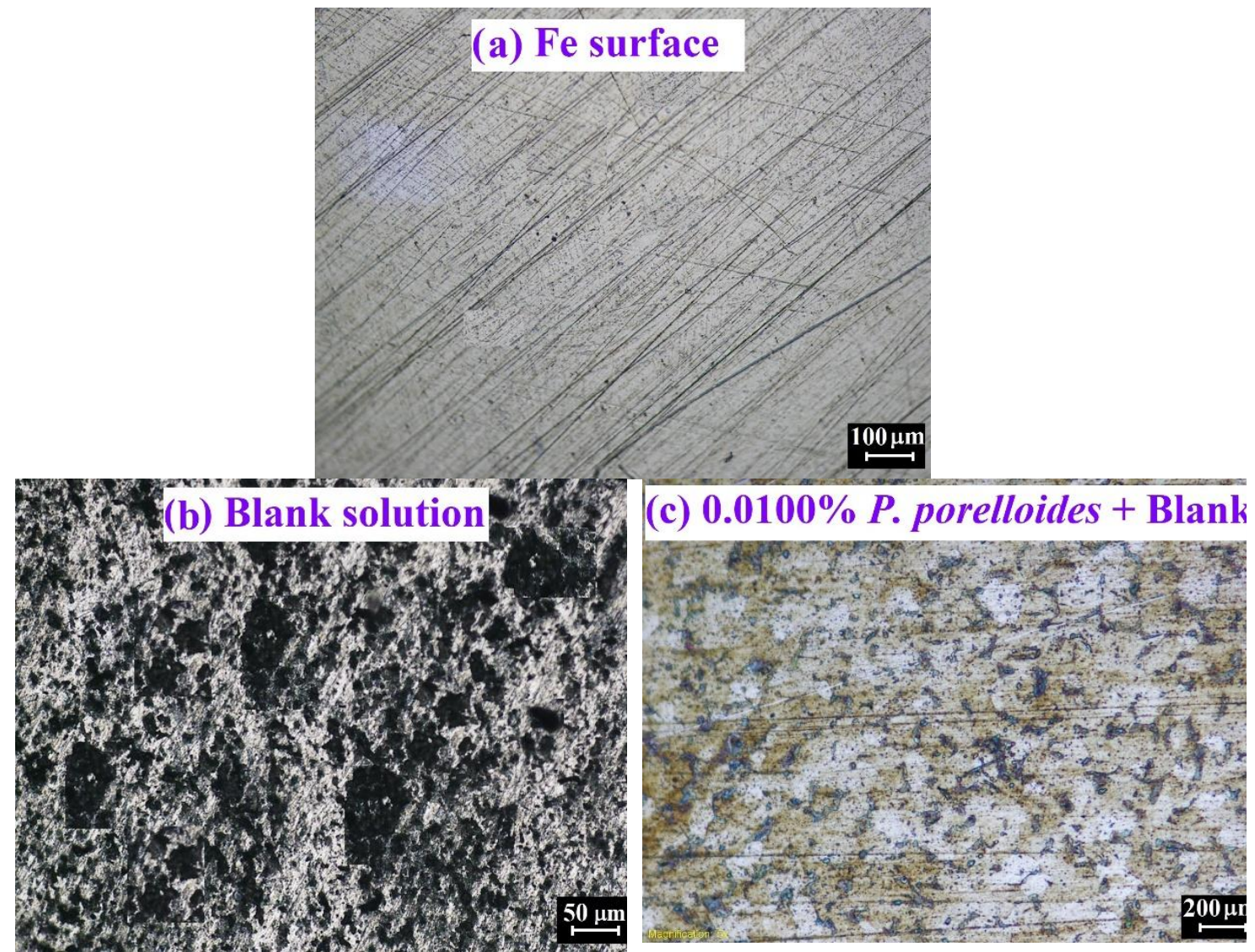

Figure 7. Optical microscope images of the working electrodes after $1 \mathrm{~h}$ at $298 \mathrm{~K}$ 
Figure 7(b) shows the surface view of the working electrode immersed in $1.0 \mathrm{M}$ hydrochloric acid solution (blank) for $1 \mathrm{~h}$. It is obvious that the surface is highly affected and deformed by the aggressive solution without inhibitors. In addition, it is seen that very prominent deep cavities and pits are formed on the surface and it has an extremely rough structure.

When it comes to Fig. 7(c), it can be seen that it has a very different appearance from Fig. 7(a) and 7(b). At the same time, on the surface of the blank solution in Fig.7(b), an almost completely smooth surface appearance stands out, in contrast to the very rough surface where the deep pits are closed. This is among the very clear evidence that the $P$. porelloides is adsorbed on the mild steel surface. It can be said that the surface image of $P$. porelloides in Figure 7(c) is extremely different from the other two surface images, there is an interaction between the metal and the green inhibitor, and this result supports the three electrochemical methods applied.

\section{Conclusions}

This study is remarkable in that it can be a solution to the phenomenon of corrosion, which cannot be prevented all over the world and has become the problem of most industries. In particular, it is an important study in terms of its first application and entry into the literature in terms of inhibiting the corrosion of mild steel in the hydrochloric acid solution of Plagiochila porelloides, a Marchantiophyta species, both as a non-toxic and completely green, nature-friendly inhibitor.

According to the results of the $1 \mathrm{~h}$ exposure experiments performed by all three electrochemical methods, it was observed that the $P$. porelloides extract was very well adsorbed on the mild steel surface and provided high inhibition even at its lowest concentrations. From the EIS findings, it was observed that as the concentration of the liverwort extract increased, the polarization resistance values increased and the $C P E$ values decreased, thus the inhibition effect increased. This is due to the increment in the number of organic molecules adsorbed on the metal surface as the inhibitor concentration increases. The EIS diagrams obtained in the inhibited solutions were in the form of a semiellipse, unlike the blank solution. Inhibition efficiency values calculated from EIS and LPR findings, $R_{p}$ and ${ }^{*} R_{p}$ values increased at the same rate as $P$. porelloides extract was added to the $\mathrm{HCl}$ solution.

The electrochemical behaviour of mild steel was examined by the potentiodynamic polarization (Tafel extrapolation) method, and the fact that the calculated $-\beta_{c}$ values did not change much in both solutions with and without inhibitor showed that the hydrogen formation mechanism was not affected by $P$. porelloides. In addition, it was concluded that $P$. porelloides behaved as a cathodic controlled mixedtype inhibitor, since the enhancement in liverwort concentration in the acidic solution diminished both anodic and cathodic current density values more dominantly in the cathodic side.

In order to analyse the effect of the inhibitor on the metal/solution interface in detail, surface images were taken, and it was observed that the surface image in the blank solution was quite rough and had large cavities compared to the image in the solution containing liverwort extract. The three electrochemical methods utilized as well as optical microscope analysis results are highly compatible with each other.

\section{Acknowledgements}

The author would like to thank, in the process of providing and identifying the plant material to Prof. Dr. Tülay Ezer, and also to Prof. Dr. Osman Seyyar for photographed of the plant material.

\section{References}

Abu-Baker A.N. Khalil L.A. Al-Gonmeen T. 2021. A multi-analytical exploration of the chemical composition, microstructural properties and corrosion inhibiting treatment for an archaeological brass censer from Umm Zuwaytinah, Amman. Nucl. Instrum. Methods Phys. Res. B. 502: 73-79.

Alrebh A. Rammal M.B. Omanovic S. 2021. A pyridine derivative 2-(2Methylaminoethyl)pyridine (MAEP) as a 'green' corrosion inhibitor for low-carbon steel in hydrochloric acid media. J. Mol. Struct. 1238:8, 130333.

Cansu T.B. Yaylı B. Özdemir T. Batan N. AlpayKaraoğlu Ş. Yaylı N. 2013. Antimicrobial activity and chemical composition of the essential oils of mosses (Hylocomium splendens (Hedw.) Schimp. and Leucodon sciuroides (Hedw.) Schwägr.) growing in Turkey. Turk. J. Chem. 37:2, 213-219.

Cansu T.B. Özdemir T. Batan N. Yaylı B. AlpayKaraoğlu Ş. Yaylı N. 2014. Essential Oil Analysis and Antimicrobial Activity of Neckera complanata (Hedw.) Huebener and Neckera crispa Hedw. (Neckeraceae) Grown in Turkey. Asian J. Chem. 26:7, 2005-2008.

Charitha B.P. Rao P. 2018. Pullulan as a potent green inhibitor for corrosion mitigation of aluminum composite: Electrochemical and 
surface studies. Int. J. Biol. Macromol. 112: 461-472.

Chaubey N. Savita. Qurashi A. Chauhan D.S. Quraishi M.A. 2021. Frontiers and advances in green and sustainable inhibitors for corrosion applications: A critical review. J. Mol. Liq. 321: 114385

El Tamany El-S.H. Elsaeed S.M. Ashour H. Zaki E.G. El Nagy H.A. 2018. Novel acrylamide ionic liquids as anti-corrosion for X-65 steel dissolution in acid medium: Adsorption, hydrogen evolution and mechanism. J. Mol. Struct. 1168: 106-114.

Feng Y. He J. Zhan Y. An J. Tan B. 2021. Insight into the anti-corrosion mechanism Veratrum root extract as a green corrosion inhibitör. J. Mol. Liq. 334: 116110.

Guruprasad A.M. Sachin H.P. 2021. Novel costeffective aqueous Amorphophallus paeoniifolius leaves extract as a green corrosion inhibitor for mild steel corrosion in hydrochloric acid medium: A detailed experimental and surface characterization studies. Chem. Data Coll. 34: 100734.

Huang Y. Xiao D. Burton-Freeman B.M. Edirisinghe I. 2016. Chemical changes of bioactive phytochemicals during thermal processing. In: Reference Module in Food Science. Elsevier.

Kumar H. Yadav V. 2020. Musa acuminata (Green corrosion inhibitor) as anti-pit and anticracking agent for mild steel in $5 \mathrm{M}$ hydrochloric acid solution. Chemical Data Collections. 29: 100500.

Li H. Qiang Y. Zhao W. Zhang S. 2021. A green Brassica oleracea $L$ extract as a novel corrosion inhibitor for Q235 steel in two typical acid media. Colloids Surf. A Physicochem. Eng. Asp. 616: 126077.

Ma L. Lu W. Yang D. Shen J. Gao Z. Zhang S. Liao Q. 2021. Dithiocarbamate modified glucose as a novel eco-friendly corrosion inhibitor for copper in sodium chloride media. Sustain. Chem. Pharm. 22: 100488.

Mao T. Huang H. Liu D. Shang X. Wang W. Wang L. 2021. Novel cationic Gemini ester surfactant as an efficient and eco-friendly corrosion inhibitor for carbon steel in $\mathrm{HCl}$ solution. J. Mol. Liq. 339: 117174.

Nam N.D. Hien P.V. Hoai N.T. Thu V.T.H. 2018. A study on the mixed corrosion inhibitor with a dominant cathodic inhibitor for mild steel in aqueous chloride solution. J. Taiwan Inst. Chem. Eng. 91: 556-569.

Özkır D. Kayakırılmaz K. Bayol E. Gürten A.A. Kandemirli F. 2012. The inhibition effect of Azure A on mild steel in $1 \mathrm{M} \mathrm{HCl}$. A complete study: Adsorption, temperature, duration and quantum chemical aspects. Corrosion Science. 56: 143-152.

Özkır D. Çifcibaşı Ö. 2017. The Investigation of the Adsorption of a Schiff Base Derivated from 2,5-Dichloroaniline as an Inhibitor on Mild Steel Corrosion in Acidic Medium by Electrochemical Methods. Engineering Sciences. 12:2, 97-107.

Özkır D. 2018. A new example of mild steel corrosion inhibitors synthesized from Chloroaniline: 2-[(2,5dichlorophenylimino) methyl] phenol. OHU J. Eng. Sci. 7:2, 993-1003.

Özkır D. 2019a. A Newly Synthesized Schiff Base Derived from Condensation Reaction of 2,5dichloroaniline and benzaldehyde: Its Applicability through Molecular Interaction on Mild Steel as an Acidic Corrosion Inhibitor by Using Electrochemical Techniques. J. Electrochem. Sci. Technol. 10:1, 37-54.

Özkır D. 2019b. The Electrochemical Variation of a Kind of Protein Staining and Food Dye as a New Corrosion Inhibitor on Mild Steel in Acidic Medium. International Journal of Electrochemistry. 2019: 1-11.

Özkır D. 2019c. A Corrosion Study: Use of Thionine dye having structurally metachromatic influence. Int. J. Chem. Technol. 3:1, 17-25.

Özkır D. Ezer T. 2020. A New Inhibitor Approach to the Corrosion of Mild Steel in Acidic Solution with Long-Term Impedance Tests: A New Application Area for Hypnum cupressiforme (Bryophyta). Anatolian Bryology. 6:2, 119-128.

Özkır D. Kayakırılmaz K. 2020. The Inhibitor Effect of (E)-5-[(4(benzyl(methyl)amino)phenyl)diazenyl]1,4-dimethyl-1H-1,2,4-triazol-4-ium zinc(II) Chloride, an Industrial Cationic Azo Dye, onto Reducing Acidic Corrosion Rate of Mild Steel. J. Electrochem. Sci. Technol. 11:3, 257-272.

Paton J.A. 1999. The Liverworts flora of the British Isles. Harley Press, 626 p. England.

Rodrigues F.A.d.S. Gonçalves Y.M.H. Horta B.A.C. Santos I.d.S. Silva B.V. D'Elia E. 2021. Experimental and theoretical studies of isonitrosoacetanilides derivatives as corrosion inhibitors for mild steel in $1 \mathrm{~mol}$ $\mathrm{L}^{-1} \mathrm{HCl}$. J. Mol. Struct. 1245: 131-256.

Salmasifar A. Edraki M. Alibakhshi E. Ramezanzadeh B. Bahlakeh G. 2021. Combined electrochemical/surface investigations and computer modeling of the aquatic Artichoke extract molecules corrosion inhibition properties on the mild 
steel surface immersed in the acidic medium. J. Mol. Liq. 327: 114856.

Smith A.J.E. 1996. The liverworts of Britain and Ireland, Cambridge University Press. 362 p. Cambridge.

Sürme Y. Gürten A.A. 2009. Role of polyethylene glycol tert-octylphenyl ether on corrosion behaviour of mild steel in acidic solution. Corros. Eng. Sci. Techn. 44:4, 304-311.

Tosun G. Yayli B. Özdemir T. Batan N. Bozdeveci A. Yayli N. 2015. Volatiles and Antimicrobial Activity of the Essential Oils of the Mosses Pseudoscleropodium purum, Eurhynchium striatum, and Eurhynchium angustirete Grown in Turkey. Rec. Nat. Prod. 9: 237-242.

Zhang X. Li W. Yu G. Zuo X. Luo W. Zhang J. Tan B. Fu A. Zhang S. 2020. Evaluation of Idesia polycarpa Maxim fruits extract as a natural green corrosion inhibitor for copper in $0.5 \mathrm{M}$ sulfuric acid solution. J. Mol. Liq. 318: 114080.

Zohdy K.M. El-Sherif R.M. Ramkumar S. ElShamy A.M. 2021. Quantum and electrochemical studies of the hydrogen evolution findings in corrosion reactions of mild steel in acidic medium. Upstream Oil and Gas Technology. 6: 100025. 